\title{
CROATIA'S POTENTIAL \\ FOR POLYCENTRIC DEVELOPMENT
}

Katarina BAČIĆ

Institute of Economics, Zagreb

Jelena ŠIŠINAČKI

Rabac

UDK: $338.1(497.5): 353$

Izvorni znanstveni rad

Primlieno: 9. 4. 2013.

The purpose of this paper is to analyse Croatia's potential to integrate the concept of polycentric development - an even development of equally spaced urban centres which also aims at lessening regional disparities - into its regional development policy. By applying the polycentricity index to the Croatian data, following Meijers and Sandberg's methodological approach (2006), Croatia is found to be moderately polycentric. However, the rank-size distribution indicates that Zagreb is too large, whereas the larger cities that follow Zagreb are insufficiently large. When using NUTS level 2 data, regional disparities in Croatia are at the level of the European Union, but when county data are used, the level of disparities increase. This indicates that polycentricity has not fully been exploited in terms of connectivity and cooperation of cities. A cross-section analysis of regional disparities in Croatia has confirmed that more successful counties have higher proportions of a workforce with higher educational attainment. Urban impact and openness to international trade appear relevant when the variable "workforce with higher educational attainment" is omitted; therefore, better performing counties have higher shares of population in their urban centres and are more open to international trade.

Keywords: polycentricity, regional development, cross-section analysis, Croatia 
The purpose of this paper is to examine whether Croatia has the potential to build its regional development policy by incorporating the principles of polycentric development. This paper follows Meijers and Sandberg's methodological framework (2006) in constructing an index of polycentricity. Following this framework, we also determine the values of three indicators measuring the level of regional disparities in Croatia. The purpose is to use these measures as an approximation of the effectiveness of the country's regional development policy. A cross-section analysis is used to determine what factors can account for the level of regional disparities across Croatia, including the level of urbanisation as an explanatory variable.

The paper consists of four parts. After the introduction, follows a theoretical overview of the various concepts of polycentricity and their use in regional development policy in the European Union (EU). In the second part of the paper, a brief overview of Croatia's regional development policy and its results are given. In the third part of the paper, the index of polycentricity and the measures of regional disparities are applied using the Croatian data. Additionally, Meijers and Sandberg's results for other European countries are used to help rank Croatia among those countries in terms of the level of polycentricity. The empirical part of the paper ends with a cross-section analysis of regional disparities for Croatia. The purpose is to establish whether urban impact in counties can account for the level of regional disparities. The paper ends with a conclusion and an assessment of the empirical results and their policy implications.

\section{POLYCENTRICITY AND ITS MEASUREMENT}

Generally speaking, polycentricity can be defined as a spatial organisation of cities that is characterised by a functional division of labour, economic and institutional integration and political co-operation (Gløersen, 2005). In other words, no city dominates over others and cities cooperate and share responsibilities with regard to many important issues. The centres are linked in networks and complement each other functionally and co-operate together. Before undertaking applied research on subjects related to "polycentricity/polycentricism", there are two closely related terms that must be clarified. Those are "polycentric development" and "polycentric development policy".

Polycentric development is a spatial and functional form of development concept that is based on polycentricity (Hague \& Kirk, 2003). Benefits to be gained from this type of devel- 
DRUŠ. ISTRAŽ. ZAGREB GOD. 23 (2014), BR. 2 STR. 327-347

BAČIĆ, K., ŠIŠINAČKI, J.: CROATIA'S POTENTIAL... opment are increased competitiveness, cohesion and regional balance, parity of access to infrastructure and knowledge and sustainable development. Polycentric development policy ensures the implementation of polycentric development in practice by addressing and enforcing a more even distribution of economic/economically relevant functions over the entire urban system (Waterhout, Zonnenveld, \& Meijers, 2005). Although this type of development concept and policy aims at a more balanced development of urban centres across a given territory, the final result should also be a more balanced regional development.

Directions for analytical monitoring of the changes in the level of polycentricity in the European Union are provided in the final report of the European Spatial Planning Observation Network (ESPON) 1.1.1. (Nordregio, 2005). More specifically, enhancing the level of polycentricity is viewed through changes in both the morphology and urban relations. Changes in morphology are reflected in an improved number of cities, their hierarchy and distribution. Changes in urban relations are reflected in the strengthening of networks of flows and co-operation between urban areas. ESPON suggested that changes in polycentricity should be monitored by using the following indicators: size index (1), location index (2) and connectivity index (3). The three different measures of polycentricity are inputs in the comprehensive index of polycentricity. According to ESPON's indices, Slovenia, Ireland, Poland and Denmark are the most polycentric countries in the European Union, while Spain, Portugal, the Nordic countries and most of Eastern Europe's accession countries are the least polycentric countries.

Polycentric patterns in the EU can be recognised at different spatial levels. On the macro level (EU), the most evident is the "zone of global integration" also referred to as the "Pentagon" because it consists of five cities: London, Hamburg, Munich, Milan and Paris. At the meso level (regional/inter-regional), polycentricity is achieved through the integration of city-regions and through the enhancement of functional complementarity. Randstad in Holland is the best example of integration of city-regions. It consists of Amsterdam (specialised in tourism, finance, transport), Utrecht (specialised in the service sector), The Hague (as the government seat) and Rotterdam (with its port) - four large cities, each thriving on a different economic basis. ${ }^{1}$

At the micro or intra-regional level, polycentricity is achieved through the improvement of economic performance by strengthening the links and improving co-operation between functional urban areas (FUAs). FUAs consist of the ur- 
ban core and surrounding area that are economically integrated with the centre. ${ }^{2}$ If a single FUA has more than 20,000 inhabitants, it is considered urban.

\section{CROATIA'S REGIONAL DEVELOPMENT POLICY}

When observed from the intra-regional or micro level, Croatia embraces a very heterogeneous territory. It is divided into 21 counties that, for the time being, also represent Croatia's regions. The country has a rather dispersed system of 127 cities (CBS, 2012). If the rank-size rule is applied, then Croatia's national urban hierarchy lacks in bigger (up to 80,000 inhabitants) and medium-sized cities (up to 30,000 inhabitants). Croatia's present urban development is based on four growth poles: Zagreb, Rijeka, Osijek and Split - cities that are spatially well distributed throughout the Croatian territory. More than 50 per cent of Croatia's population lives in those cities and the level of urbanisation amounts to 64 per cent.

From a geographic point of view, common traits can be found in the cities in the coastal area (including the islands) and in the cities in the continental area or more specifically, in the cities founded on riverbanks. Throughout history, all cities in the coastal zone have played an important role in the country's development, but today they can be regarded as smaller cities given their size and population. Cities located on the islands have local significance. Within the continental area, the capital Zagreb clearly dominates as both the political and economic centre of the country. In continental Croatia there are also many other important cities that developed on riverbanks. However, between those two described areas there is a vast space with small towns that are less significant in terms of regional development.

The existing regional development policy in Croatia is clearly stipulated in the Strategy of Regional Development of the Republic of Croatia for the period 2011 - 2013 (MRDEUF, 2010). The Strategy aims at strengthening the competitiveness of regions and local areas and at balancing out regional differences. The Strategy's main areas of concern are counties and statistical regions NUTS level 2. Although there is no notion of polycentric development or of further developing the national urban system in this policy document, its instruments and goals are indirectly supportive of polycentric development for example, developing transportation infrastructure, supporting entrepreneurial growth and infrastructure, sustainable management of environment and energy resources as well as sustainable management of cultural and natural goods, all of which could also provide better growth opportunities for less developed cities. 
DRUŠ. ISTRAŽ. ZAGREB GOD. 23 (2014), BR. 2 STR. 327-347

BAČIĆ, K., ŠIŠINAČKI, J.: CROATIA'S POTENTIAL...
The idea of integrating polycentric development into Croatia's regional policy can be found in some important policy documents. In the late 1990s, The Spatial Planning Strategy of the Republic of Croatia and The Spatial Planning Programme of the Republic of Croatia (MSPRC, 1997, 1999) both explicitly envisaged polycentric development as the strategy for future regional development in Croatia. According to those documents, around 600 local settlements were expected to become growth initiators, while a network of cities and more important settlements were going to be built in the long run. The importance of future cross-border cooperation between cities, which was also stressed in those policy documents, was clearly aimed at implementing polycentric development on an intra-regional scale.

Regional development policy in Croatia can also be seen through spatial planning - regional development plans developed by counties. Spatial planning has insofar been orientated towards producing individual spatial plans that serve as policy documents that define the use of space but not its development. Kranjčević $(2005$, p. 233) makes a point that these plans are not coordinated with sectoral development plans (for example, in agriculture, forestry, tourism, mining, culture and transportation infrastructure), thus hindering development of individual sectors. She also identified several problem areas in spatial planning in Croatia inherent to the transitional phase in the Croatian economy and society and established (the source of) the inadequate capacity of the local administrative units (municipalities and cities) to take responsibility for managing space and lack of finance. Furthermore, similar problems also appear at the level of counties.

The Croatian development strategy from 2006 envisaged the polycentric development of Croatian regions as one of the key objectives of Croatia's spatial and regional development (Government of the Republic of Croatia, 2006). The concept was also integrated into policy documents at sectoral level. The Ministry of Education, Science and Sports made efforts to strengthen and develop regional centres of higher education and research with the aim of relieving the pressure away from Zagreb and moving the focus towards regional centres of education and research. This goal is further stressed and supported in the Government program for the period 2011 - 2015 (Government of the Republic of Croatia, 2011).

Some processes and actions aimed at balancing the level of development among Croatian regions can also be seen as compliant with the principles of polycentric development. Such is the development of the national motorway network (Government of the Republic of Croatia, 2004) from which cities that have so far been overlooked may benefit. Another advantage can be seen in lessening the drain of resources (hu- 
DRUŠ. ISTRAŽ. ZAGREB GOD. 23 (2014), BR. 2, STR. 327-347

BAČIĆ, K., ŠIŠINAČKI, J.: CROATIA'S POTENTIAL... man, capital, etc.) towards the country's capital. ${ }^{3}$ Further effort to strengthen the role of 32 bigger cities that have been identified as focal development points has been made within the prioritised decentralization process.

In conclusion, the concept of polycentricity is not new to Croatian spatial planners and researchers as the country indeed has a long tradition in urban development that has resulted in a well-connected network of cities. However, the prominent role of the capital - Zagreb during the last half of the 20th century was additionally strengthened during the Homeland War in the first half of the 1990s when the population increased due to the inflow of displaced persons seeking safety. The end result is that monocentricity is present in the development within a system that by all other basic indictors can be considered polycentric. Only recently, and particularly in the light of Croatia's accession to the EU, has the concept of polycentric development been considered as an integrative development concept. The results of the analysis in the following part of the paper should be conclusive about Croatia's potential to implement the concept of polycentric development.

\section{APPLYING THE INDEX OF POLYCENTRICITY TO THE CROATIAN DATA}

The task of this part of the paper is to determine whether Croatia has enough potential to implement the concept of polycentric development within its regional development policy. The potential should be reflected in the appropriate values of indicators that are used for measuring the degree of polycentricity on a European scale. For that purpose, we use the methodological framework designed by Meijers and Sandberg (2006) who constructed an index of polycentricity that is composed of two sub-components that help determine levels of a country's polycentricity based on different relevant non-economic variables. The first sub-component is built on the rank-size distribution of cities within a country and the second sub-component is composed on the spatial distribution of cities across the national territory.

\section{Rank-size distribution}

A polycentric national urban system is characterized by cities of similar size where no city dominates over others in important aspects. The rank-size distribution is used for measuring the degree of (non-) dominance of cities on a national scale, taking into account the size of the cities approximated by the city population and the ranking of those cities within a country.

For the purpose of constructing the sub-component, we take the 10 largest Croatian cities with a population of at least 20,000 inhabitants in 2011, in line with the definition of FUAs. 
DRUŠ. ISTRAŽ. ZAGREB GOD. 23 (2014), BR. 2, STR. 327-347

BAČIĆ, K., ŠIŠINAČKI, J.: CROATIA'S POTENTIAL.

$\rightarrow$ FIGURE

Rank-size distribution of the 10 largest Croatian cities in 2011

$\rightarrow$ FIGURE 2 Rank-size distribution of the 20 largest Croatian cities in 2011
Following Meijers and Sandberg's methodology, we set an equation with logarithmic values of city populations as a dependant variable and their respective ranks within the country as the only explanatory variable. The coefficient before the explanatory variable (the slope) will be used as the reference value in the sub-component. The explanation holds: the steeper the slope, the higher the level of monocentricity on a national level, and vice versa. The robustness of the results is checked by expanding the sample to the 20 largest cities.
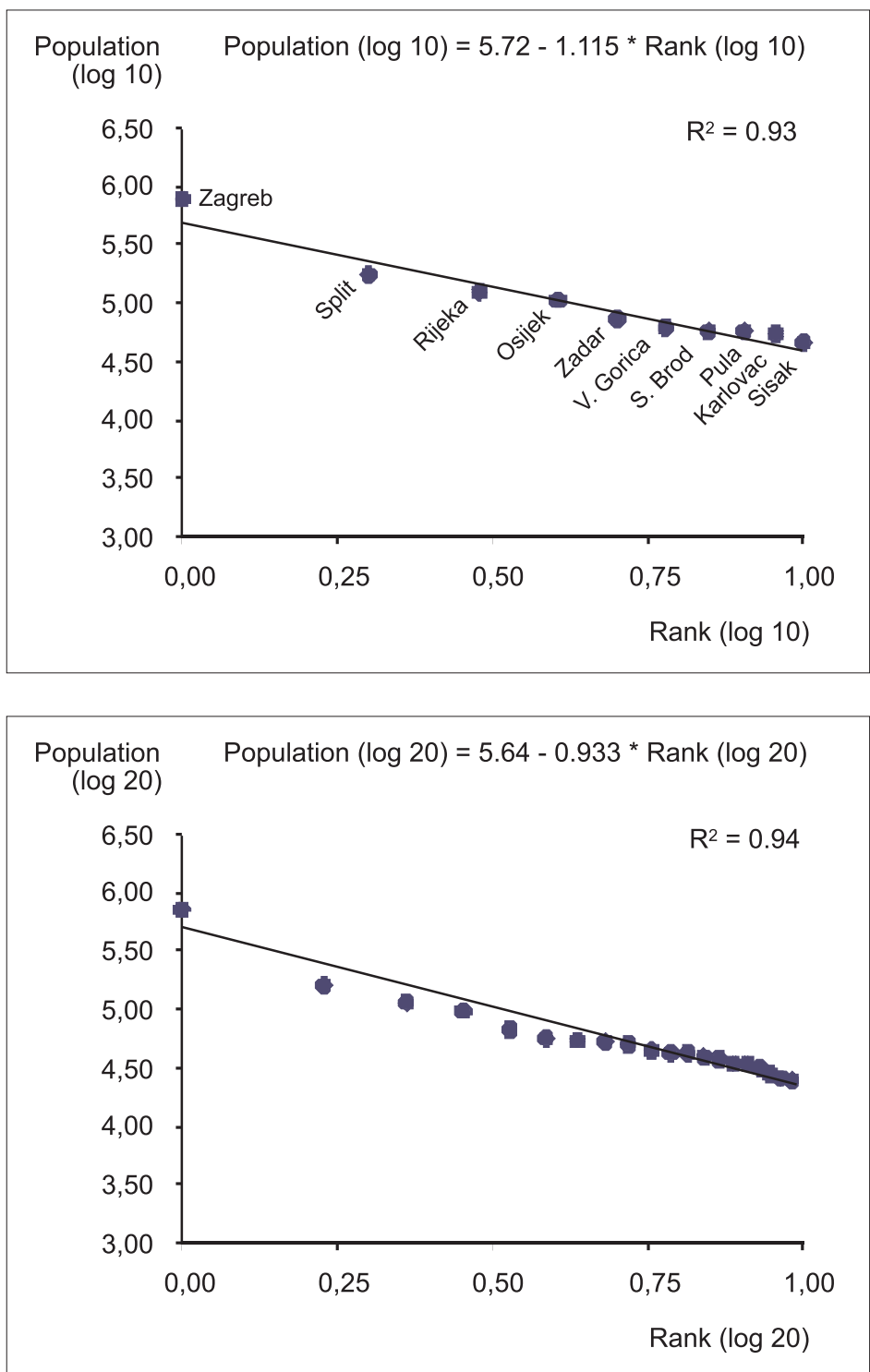

Source (Fig. 1, Fig. 2): Calculations using the Croatian Statistical Bureau (CSB) data (2011). 
DRUŠ. ISTRAŽ. ZAGREB GOD. 23 (2014), BR. 2, STR. 327-347

BAČIĆ, K., ŠIŠINAČKI, J.: CROATIA'S POTENTIAL...

O SCENARIO

The ideal rank-size distribution of 10 largest cities in the present situation (2011) with Zagreb remaining the same size. Calculations using the CSB data (2011)
Figure 1 shows that Croatia, according to the rank-size distribution of its largest cities, is more polycentric than monocentric. This can be seen in the relatively low value of the coefficient before the explanatory variable as well as in the relatively flat regression line. Croatia's values of rank-size score for the top 10 and 20 largest cities $(-1,115$ and $-0,933)$ are at the level of the European average: -1,116 in Meijers and Sandberg (2006) and -0,96 in ESPON 1.1.1. (Nordregio, 2005). Estimated equations for both the 10 and 20 largest cities do not differ significantly. However, the result of the equation for the 20 largest cities implies a higher level of polycentricism due to a more even rank-size distribution of cities with a population of $50,000-75,000$, at the end of the regression line. It is evident in both figures that the City of Zagreb, as the capital, with 792,875 inhabitants is too large in the distribution seeing as it lies above the regression line. There is also a gap in the ranking between Zagreb and the next two largest cities - Split and Rijeka, which, together with their position below the regression line, implies an absence of a class of cities following Zagreb. In an ideal situation, where cities following Zagreb would complement and counterbalance Zagreb in their size, Split and Rijeka's population would be double compared to the present population (Scenario 1).

\begin{tabular}{rlr}
\hline 1 & Zagreb & 792.875 \\
2 & Split & 366.063 \\
3 & Rijeka & 232.924 \\
4 & Osijek & 169.008 \\
5 & Zadar & 131.781 \\
6 & Velika Gorica & 107.539 \\
7 & Slavonski Brod & 90.557 \\
8 & Pula & 78.030 \\
9 & Karlovac & 68.426 \\
10 & Sisak & 60.842 \\
\hline
\end{tabular}

The question that arises from the results is whether $\mathrm{Za}$ greb's size and position in the current rank-size distribution should be tackled. This issue should be approached from two angles. Firstly, Zagreb should be viewed in the European context. In that case, Zagreb as an urban centre competes (for investors, projects, positioning itself as centre for various organizations and institutions, etc.) and, at the same time, cooperates with other European cities of similar importance and creates functional links (for example, in transportation). Second$l y$, Zagreb is a major engine of growth for the country and its development should not be restrained, but only managed in a sustainable and balanced manner. 
DRUŠ. ISTRAŽ. ZAGREB GOD. 23 (2014), BR. 2 STR. 327-347

BAČIĆ, K., ŠIŠINAČKI, J.: CROATIA'S POTENTIAL...
Typically, most EU countries stipulate diminishing and overcoming differences and the dominance of the capital as a policy goal in their polycentric development policies or as part of their regional development policies. A caveat in the Croatian case for this goal should be considered, based on the conclusion of the VISION PLANET working team that was drawing up a spatial vision for the Central European, Adriatic, Danubian and South Eastern Space (CADSES) countries which states that "equity-oriented approach must be implemented cautiously considering that in most countries only a few regions and cities are carriers of competitiveness, foreign investment, export and growth, their support in creating better conditions for efficient business is of vital interest to the national economy as a whole." (VISION PLANET Working Team, 2000, p. 9 in Meijers, Waterhout, \& Zonneveld, 2007, p. 16).

Reducing gaps between the capital and other classes of cities is sometimes followed by another - reducing gaps between classes of (less advantaged) cities in national regions. For example, finance is provided for joint development projects of urban centres other than the capital, public administrative bodies are located in different cities and inter-city competition is encouraged up to the point where more territorial cohesion is achieved (Meijers et al., 2007). A balanced approach to sectoral policies (transport, energy, maritime, agricultural, employment, environmental and other policies) can also be supportive of polycentric development goals.

\section{Spatial distribution of cities}

Polycentricity is additionally characterized by an even distribution of cities of the same size in an observed territory. The second sub-component of the polycentricity index encompasses that particular feature of the concept. Meijers and Sandberg (2006) use the ratio of the total number of NUTS level 2 regions and the number of NUTS level 2 regions where the largest cities are present as a measure of the second sub-component. For example, if a country has ten NUTS level 2 regions, then only the ten largest cities are considered. If those ten largest cities are present in 7 regions, then the score will amount to $7 / 10=0,700$.

Croatia's NUTS classification was changed in 2013. Up to 2013 Croatia consisted of three NUTS level 2 regions - North-West Croatia, Middle and East Croatia and Adriatic Croatia. Since 2013 the number of NUTS level 2 regions has been reduced to two and those are Continental Croatia and Adriatic Croatia (Map 1). We use both classifications to check the measure of spatial distribution of the largest cities in Croatia. 
(1) MAP 1

NUTS level 2, NUTS

level 3 and 10 largest

cities in Croatia in

2013

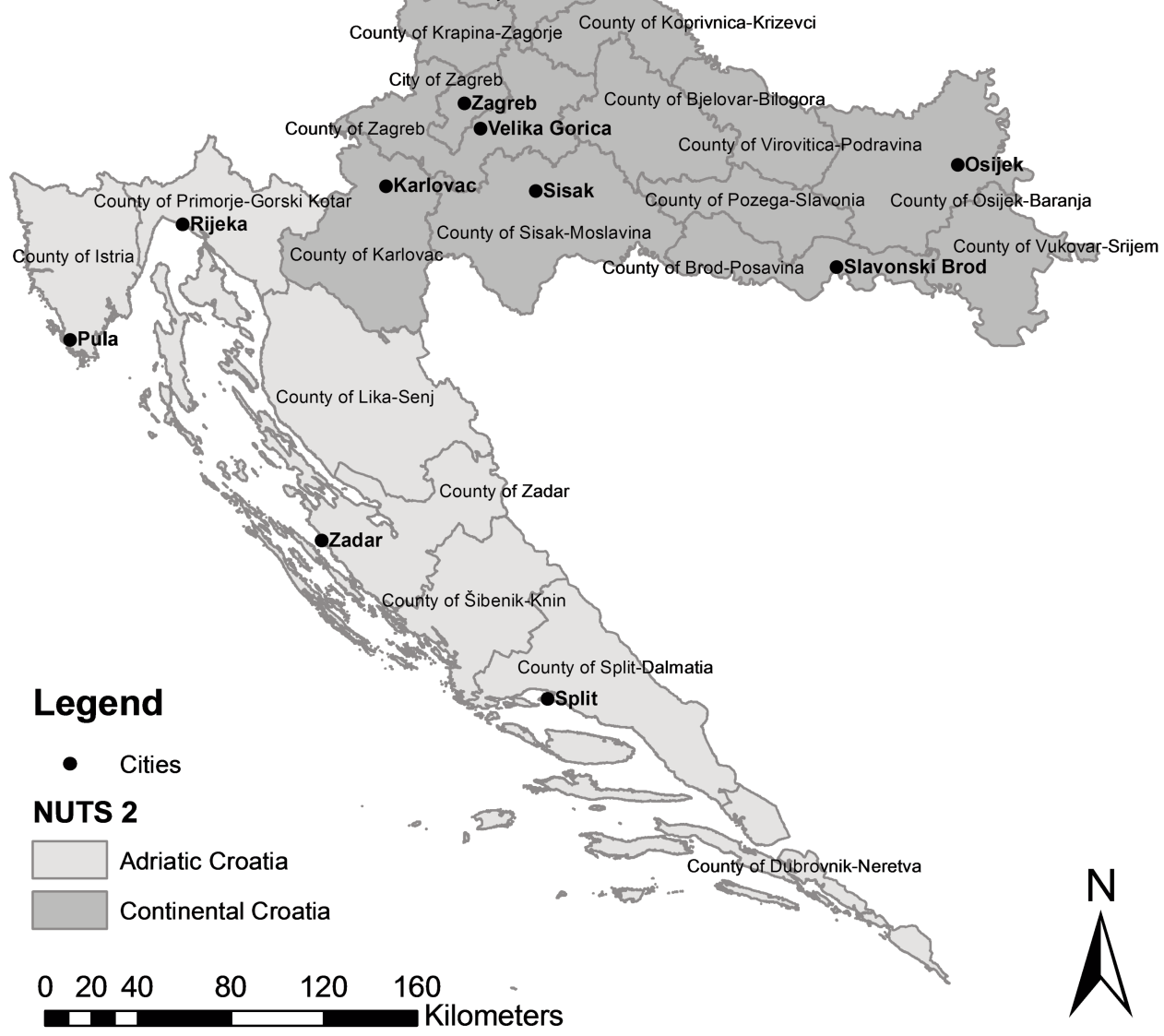

Sources: Map - GADM database of Global Administrative Areas; Cities - OpenStreetMap. Available at http://www.openstreetmap.org/

Spatial distribution of the three largest cities using the pre-2013 NUTS 2 classification yields a result of 0,7, whereas the after-2013 NUTS 2 classification implies checking the spatial distribution of the two largest cities and yields a perfect result $-1,00$ (Table 1 ).

As in the case of rank-size distribution score, Croatia again appears more polycentric than monocentric when the average score of other European countries (0.714 in Meijers and Sandberg (2006)) is considered. In this respect, Croatia is, following the new NUTS level 2 classification, high above the European average. 


\begin{tabular}{|c|c|c|c|}
\hline \multirow{2}{*}{$\begin{array}{l}\text { (1) TABLE } 1 \\
\text { Spatial distribution of the } \\
\text { largest cities using pre- } \\
\text { and after- } 2013 \text { NUTS2 } \\
\text { classification (2011) }\end{array}$} & \\
\hline & $\begin{array}{l}\text { Pre-2013 } \\
\text { classification }\end{array}$ & & $\begin{array}{l}\text { After-2013 } \\
\text { classification }\end{array}$ \\
\hline $\begin{array}{l}\text { NUTS } 2 \\
N=3\end{array}$ & 3 largest cities & $\begin{array}{l}\text { NUTS } 2 \\
\mathrm{~N}=2\end{array}$ & 2 largest cities \\
\hline North-West Croatia & Zagreb & Continental Croatia & Zagreb \\
\hline Middle and East Croatia & & & / \\
\hline Adriatic Croatia & $\begin{array}{l}\text { Split } \\
\text { Rijeka }\end{array}$ & Adriatic Croatia & Split \\
\hline $\begin{array}{l}\text { Number of regions where } \\
\text { the } 3 \text { largest cities are present }\end{array}$ & 2 & $\begin{array}{l}\text { Number of regions where } \\
\text { the } 2 \text { largest cities are present }\end{array}$ & 2 \\
\hline Spatial distribution score & 0,7 & Spatial distribution score & 1 \\
\hline
\end{tabular}

Source: Calculations using the CSB data (2011).

\section{The index of polycentricity}

Meijers and Sandberg (2006) transform both measures of polycentricity linearly into standardized z-scores (where mean z-value is 0 , and standard deviation is 1 ) in order to construct the polycentricity index. We carry out the transformation using the expression:

$$
z_{i}=\left(x_{i}-\bar{x}\right)^{-1} \sigma, \text { where } \mathrm{i}=1,2, . ., \mathrm{N} \quad \text { Equation } 1 .
$$

A z-score of 0 is given a value of 100 , and 1 standard deviation is given a value of 20 . So far, constructing and using proposed measures was possible quite independently by using the Croatian data alone. However, constructing the polycentricity index within the outlined methodological framework requires using scores that Meijers and Sandberg (2006) deter-

(1) TABLE 2

The composite index of polycentricity for Croatia in 2011 mined for their sample of countries. Mean and standard deviation are determined using those data.

\begin{tabular}{ccccc}
\hline Rank-size score & Mean & Standard deviation & Z-score & Rank-size index \\
$-1,12$ & $-1,12$ & 0,35 & 0,004 & 100,08 \\
Spatial distribution score & Mean & Standard deviation & Z-score & Spatial distribution index \\
0,67 & 0,71 & 0,11 & 0,83 & 116,68 \\
Index of polycentricity for Croatia & & & 108,38 \\
\hline
\end{tabular}

Croatia can be considered polycentric by both rank-size and spatial distribution score. Therefore, the high level of the index of polycentricity for Croatia is not surprising (Table 2). Croatia $(108,38)$ ranks above the European average $(99,71$ in Meijers and Sandberg (2006)). We further proceed with research on regional disparities. We intend to find out wheth- 
er Croatia's good results of polycentricity measures can possibly be linked to the lower level of regional disparities.

\section{Measuring regional disparities - the EU and Croatia}

As stated earlier, applying the concept of polycentric development should lead to a more balanced development of regions. The ESPON 1.1.1. Project Report (Nordregio, 2005) established that this holds true for the old EU Member States countries with a relatively more polycentric spatial structure are economically more successful, but this is not the case in accession countries. Those countries are on average more polycentric than the old Member States, but this does not contribute to spatial cohesion.

That raises the question of the level of regional disparities in Croatia at present and how Croatia compares to the EU. We therefore proceed with determining the level of regional disparities in Croatia and the EU countries by applying two standard measures, the coefficient of variation $(\mathrm{V})$ and the Theil index, to GDP per capita data on NUTS level 2. Both measures can be used to approximate the success of the present regional development in a country. The coefficient of variation is defined as the ratio of standard deviation to the mean and can be interpreted as the average percentage variation from the mean:

$$
C V=\sigma \cdot \bar{x}^{-1} \cdot 100
$$

Equation 2.

The index value is reported from 0-100 per cent and in this case the higher value of the index will correspond to a higher level of regional disparities and vice versa. We further pursue the form of the Theil index used by Meijers and Sandberg (2006):

$$
\mathrm{T}=\sum_{i=1}^{N}\left(\frac{\mathrm{x}_{i}}{\sum_{j=1}^{N} \mathrm{x}_{j}} \cdot \ln \frac{\mathrm{x}_{i}}{\overline{\mathrm{x}}}\right)
$$

Equation 3.

where $x_{i}$ is the Gross Domestic Product (GDP) of the $i$ th region, $\bar{x}$ is the mean GDP, and $\mathrm{N}$ is the number of regions. The index value would be 0 if GDP was identical in all regions. Therefore, the lower the value of the T index, the lower the level of regional disparities in the country. Results are given in Table 3.

As the results indicate, regional disparities exist in Croatia, as well as in every European country. On average, GDP per capita in three NUTS level 2 Croatian regions varies on average up to 28 percent from the average GDP per capita. Compared to the year 2001, in 2009 the level of regional dis- 
$\rightarrow$ TABLE 3

Regional disparities across Europe in 200 and 2009 using NUTS level 2 classification parities across Europe and in Croatia increased. In the case of the EU, this was mostly due to an increase in regional disparities in the new Member States, most notably in Bulgaria, Romania and Slovakia.

\begin{tabular}{|c|c|c|c|c|}
\hline & \multicolumn{2}{|r|}{2001} & \multicolumn{2}{|r|}{2009} \\
\hline & $\mathrm{CV}$ & Theil-index & $\mathrm{CV}$ & Theil-index \\
\hline Belgium & 38,3 & 0,07 & 34,6 & 0,06 \\
\hline Bulgaria & 19,7 & 0,04 & 41,4 & 0,07 \\
\hline Croatia & 25,1 & 0,02 & 28,4 & 0,03 \\
\hline Czech Republic & 41,1 & 0,06 & 42,6 & 0,07 \\
\hline Denmark & 16,2 & 0,01 & 18,7 & 0,01 \\
\hline Germany & 24,2 & 0,03 & 21,0 & 0,02 \\
\hline Ireland & 31,1 & 0,02 & 32,6 & 0,03 \\
\hline Greece & 13,7 & 0,01 & 19,5 & 0,02 \\
\hline Spain & 20,6 & 0,02 & 18,0 & 0,02 \\
\hline France & 20,8 & 0,02 & 21,5 & 0,02 \\
\hline Italy & - & - & 24,6 & 0,03 \\
\hline Hungary & - & - & 39,9 & 0,06 \\
\hline Netherlands & 15,6 & 0,01 & 16,3 & 0,01 \\
\hline Austria & - & - & 17,3 & 0,01 \\
\hline Poland & 21,8 & 0,02 & 23,8 & 0,02 \\
\hline Portugal & 19,3 & 0,02 & 21,5 & 0,02 \\
\hline Romania & 33,8 & 0,04 & 45,6 & 0,08 \\
\hline Slovakia & 57,4 & 0,11 & 68,2 & 0,15 \\
\hline Finland & 25,2 & 0,03 & 24,8 & 0,03 \\
\hline Sweden & 15,9 & 0,01 & 19,6 & 0,02 \\
\hline United Kingdom & 32,5 & 0,04 & 38,8 & 0,05 \\
\hline Average & 26,2 & 0,03 & 29,5 & 0,04 \\
\hline
\end{tabular}

Source: Calculations using Eurostat data and the CSB data.

When these measures are applied to the county data in Croatia for the year 2009 and to the rate of unemployment data, the measures yield more unfavourable results (Table 4), suggesting thus greater regional disparities. The Theil index component value across counties is found negative in 14 Croatian counties and indicates that those counties are laggards, while seven counties with positive values represent counties that are better off than the average.

The two-tier level data and its analysis yielded inconclusive results on the link between regional disparities and polycentricity. The results have shown that spatial measures of polycentricity, whereby Croatia can be considered moderately polycentric, correspond to Croatia's level of regional disparities that is approximately at the level of the European Union average when NUTS level 2 is considered. However, disparities are more prominent when the level of counties is considered, indicating a more unfavourable position of Croatia, with no obvious positive effect from the polycentricity issue. 


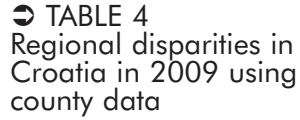

county data

\begin{tabular}{|c|c|c|c|}
\hline Counties (21) & $\begin{array}{r}\text { GDP per } \\
\text { capita } \\
\text { in EUR }\end{array}$ & $\begin{array}{r}\text { Rate of } \\
\text { unem- } \\
\text { ployment }\end{array}$ & $\begin{array}{r}\text { Theil index } \\
\text { components } \\
\text { (GDP } \\
\text { per capita) }\end{array}$ \\
\hline City of Zagreb & 17.814 & 6,1 & 0,078 \\
\hline County of Zagreb & 7.803 & 13,7 & $-0,005$ \\
\hline County of Krapina-Zagorje & 6.576 & 12,8 & $-0,011$ \\
\hline County of Varaždin & 8.834 & 11,1 & 0,001 \\
\hline County of Koprivnica-Križevci & 9.371 & 13,6 & 0,004 \\
\hline County of Međimurje & 8.349 & 12,6 & $-0,002$ \\
\hline County of Bjelovar-Bilogora & 7.677 & 24,2 & $-0,006$ \\
\hline County of Virovitica-Podravina & 6.399 & 26,5 & $-0,012$ \\
\hline County of Požega-Slavonia & 6.229 & 21,1 & $-0,013$ \\
\hline County of Slavonski Brod-Posavina & 5.606 & 25,9 & $-0,015$ \\
\hline County of Osijek-Baranja & 8.112 & 23,3 & $-0,003$ \\
\hline County of Vukovar-Sirmium & 5.974 & 27,5 & $-0,014$ \\
\hline County of Karlovac & 7.634 & 23,6 & $-0,006$ \\
\hline County of Sisak-Moslavina & 8.325 & 27,6 & $-0,002$ \\
\hline County of Primorje-Gorski Kotar & 12.305 & 10,8 & 0,026 \\
\hline County of Lika-Senj & 8.707 & 17,7 & 0,000 \\
\hline County of Zadar & 8.388 & 16,5 & $-0,002$ \\
\hline County of Šibenik-Knin & 7.239 & 19,0 & $-0,008$ \\
\hline County of Split-Dalmatia & 7.952 & 17,9 & $-0,004$ \\
\hline County of Istria & 12.810 & 7,1 & 0,030 \\
\hline County of Dubrovnik-Neretva & 9.990 & 13,1 & 0,009 \\
\hline Mean & 8671,1 & 17,7 & \\
\hline Standard deviation & 2778,2 & 6,7 & \\
\hline Coefficient of variation & 32,0 & 38,0 & \\
\hline Theil index & & & 0,04 \\
\hline
\end{tabular}

Source: Calculations for Croatia using the CSB data (2012) and the Croatian Employment Service data.

\section{Cross-section analysis of regional disparities}

We proceed with the empirical analysis by doing a cross-section analysis of Croatian regions for the year 2009 using the CBS and the Croatian Employment Service data. The purpose is to determine what factors can account for the level of disparities across Croatian regions in that year. In particular, we are interested in finding out whether the presence of FUAs in counties can account for the level of regional disparities. In other words, we are interested in learning whether a FUA with stronger impact can account for better economic performance of more advanced regions and vice-versa. This represents a minor adjustment to the level of urbanization variable (usually signifying the percentage of a country's population 
DRUŠ. ISTRAŽ. ZAGREB GOD. 23 (2014), BR. 2 STR. 327-347

BAČIĆ, K., ŠIŠINAČKI, J.: CROATIA'S POTENTIAL... living in urban areas) that can usually be found in models that try to find evidence of convergence between regions or countries over time. However, the model that we set up in this paper is one-dimensional. Therefore it represents an exercise and does not rely on any theoretical approach. We use the Theil index components for GDP per capita (THEIL) across counties as a dependent variable, as the overall index represents a measure of regional disparities.

The explanatory variables are:

Demographic dependency rate (DEMO), defined as the ratio of population over 65 years of age and the population between 15 to 64 years of age in each county. We expect this variable to have a negative sign in the cross-section regression.

Educational attainment (EDUC), defined as the ratio of working population with tertiary education in the population above 15 years of age. We expect this variable to have a positive sign in the cross-section regression.

Industrial employment (EM_IND), defined as the share of persons employed in industry in the total labour force. We expect this variable to have a positive sign in the cross-section regression.

Rate of unemployment (UNEM), defined as the ratio of unemployed persons in the total working population. We expect this variable to have a negative sign in the cross-section regression.

Level of urbanization (URB), defined as the ratio of population in FUA (above 20,000 inhabitants, if applicable) ${ }^{4}$ and the total population in the observed county. We expect this variable to have a positive sign in the cross-section regression.

External competitiveness (EXT), defined as the share of merchandise export and imports of a region in the aggregate regional GDP. We expect this variable to have a positive sign in the cross-section regression.

Therefore, the model is defined as:

THEIL $=\mathrm{f}($ DEMO, EDUC, EM_IND, UNEM, URB, EXT)

The model is applied to all the Croatian counties. The model has passed all the diagnostic tests. Heteroscedasticity was not present and residuals were distributed normally. The results are presented in Table 5 . In addition, the model is applied to a dataset where the City of Zagreb is omitted, leaving 20 counties in the test with the purpose to check whether Zagreb's dominance and specific traits can influence the test results. However, the results of testing the models on both datasets do not differ significantly, so all counties were included. 
? TABLE 5

Main results of regression analyses of disparities across Croatian counties in 2009 (the Theil index component as the dependant variable)

\begin{tabular}{lrr}
\hline Specifications of the model (1-2) & \multicolumn{1}{c}{$\begin{array}{r}2 \\
\text { Unstandardised regression } \\
\text { coefficient (p-value) }\end{array}$} \\
\cline { 2 - 3 } Independent Variables & $0,026(0,63)$ & $-0,076(0,33)$ \\
Demographic dependency rate & $0,422(0,00)$ & $/$ \\
Educational attainment & $-0,000(0,08)$ & $-0,002(0,00)$ \\
Rate of unemployment & $0,024(0,70)$ & $-0,123(0,16)$ \\
Industrial employment & $0,005(0,84)$ & $0,084(0,00)$ \\
Level of urbanization & $0,007(0,61)$ & $0,043(0,04)$ \\
External competitiveness & $-0,037(0,04)$ & $-0,005(0,83)$ \\
Constant & 0,90 & 0,76 \\
Adjusted R-squared & & \\
\hline
\end{tabular}

Remark: Independent variables are each set within their own scale.

The model is estimated using two specifications, with the first model including all the explanatory variables, while in the following model specification, the explanatory variable found significant in the first model is omitted. Since independent variables are each set within their own scale, the values of regression coefficients are not comparable. The results show that educational attainment is a significant variable. The more educated workforce is a basis for attracting higher-value added economic activities and investment as well as the principal carrier of entrepreneurial activity. When the model is tested with the variable "educational attainment" omitted, the level of urbanization and the external competitiveness account for the variation in regional differences. It would suggest that more successful counties are counties with more populated FUAs and that these urban centres may have a positive impact on the counties' economic performance by attracting more high-income economic activities, investment, better educated work force, by providing infrastructure and services for the businesses (factors that could provide better entrepreneurial and employment opportunities for out-of-FUA county population and increase the standard of living of the whole county as a result). However, more empirical evidence is needed to support the assumptions of dynamic relationships. External competitiveness is basically a measure of openness to trade. The results show that counties that are more open to trade are more economically successful counties. These counties exploit their competitive advantages by trading internationally. Demographic dependency rate, rate of unemployment (with the regression coefficient close to zero) and industrial employment appear insignificant in the model. The peculiar finding on the role of industrial employment can be explained by a diminishing industrial base in Croatia. Industrial employment has gradually been decreas- 
DRUŠ. ISTRAŽ. ZAGREB GOD. 23 (2014), BR. 2 STR. 327-347

BAČIĆ, K., ŠIŠINAČKI, J.: CROATIA'S POTENTIAL...

\section{CONCLUSION}

ing from the onset of the economic transition due to a number of reasons (loss of product competitiveness, inability to compete on cost-basis, technological aging, to name just a few) with the economy turning mostly towards the services sector. It must be noted, though, that the analysis is carried out on a small number of observations and is period-specific. In order to be able to come to firm conclusions on polycentric development and disparities issue, a more elaborate model is required. One possible extension is a more sophisticated indicator of urban impact. Another necessary extension is analysing a longer time period to be able to discuss dynamic relations between variables. Both aspects would contribute to more robust results.

The main task of this paper was to establish whether Croatia has enough potential to integrate the concept of polycentricity into its regional policy and this potential was confirmed with the results of an empirical analysis. Firstly, polycentricity was measured following Meijers and Sandberg's methodological framework (2006): index of polycentricity is composed of a measure of rank-size distribution of the 10 largest cities and a measure of spatial distribution of the cities across NUTS level 2 in the country. Croatia can be considered polycentric by both rank-size and spatial distribution score. The graphic representation of the rank-size distribution indicates that Zagreb is too dominant by size in the national urban system, while larger cities following Zagreb are insufficiently large.

The success of a country's regional development policy can be approximated by the level of its regional disparities. We used the Theil index to measure the level of regional disparities for GDP per capita in Croatia and the selected countries of the EU for NUTS level 2 data. We also repeated this measurement for 21 Croatian counties and we can confirm the consistency of results for counties with the coefficient of variation for the rate of unemployment. The two-tier level data and its analysis yielded inconclusive results on the link between regional disparities and polycentricity. The results show that Croatia's level of regional disparities is approximately at the level of the European Union average when NUTS level 2 is considered. However, at the level of counties' data, disparities are more prominent. With regard to the effect of polycentricity, an explanation for the latter results could be that Croatia's favourable level of spatial polycentricity has not fully been exploited in terms of connectivity and cooperation of cities. 
DRUŠ. ISTRAŽ. ZAGREB GOD. 23 (2014), BR. 2, STR. 327-347

BAČIĆ, K., ŠIŠINAČKI, J.: CROATIA'S POTENTIAL...

\section{Discussion}

The third part of the analysis was focused on identifying the factors behind the regional disparities across the Croatian territory. More importantly, we were interested in finding out whether urban impact is a relevant factor for regional differences in Croatia. To this end, we used a cross-section analysis of counties with the Theil index component value as the dependent variable. The results show that the existing level of regional disparities could most strongly be associated with the differences in educational attainment of the workforce: better performing counties are counties with higher shares of better educated workforce. When the variable "educational attainment" is omitted from the model specification, urban impact and openness to trade appear relevant in explaining regional differences.

The analysis in this paper has given an empirical justification for integrating the concept of polycentricity into Croatia's regional development policy and in the light of Croatia's accession to the EU, this concept is an obvious policy choice. In planning its regional and urban development, Croatia is already relying on the directions given for the EU Member States. Within spatial planning, polycentric development was incorporated into strategic policy documents already in 1997. For policy-makers, the question remains - how to empower the periphery and at the same time not cause the drain of resources from the centre and, how to increase competitiveness of the whole country?

From a macro-scale perspective, the City of Zagreb as the capital could join the third potential zone of global economic integration (Vienna-Bratislava-Prague-Dresden-Berlin) as cultural, transportation and communication connections are quite well developed. Zagreb's regional importance implies that its competitiveness, development and growth should not be restrained and viewed only through the configuration of the national urban system, but balanced out with the growth of similar European urban centres in terms of size and importance as well as with that of the Croatian urban centres.

We do not attempt to propose an integrated policy concept based on the results of the research that was carried out in this paper. It should be noted that this may require further research and assessment of the role of medium-sized cities in Croatia within the national urban system and that of the issue of connectivity of urban centres. Many European countries, along with the most common policy of reducing differences between the capital and the class of following cities, also focus on reducing gaps between classes of cities within national 
DRUŠ. ISTRAŽ. ZAGREB GOD. 23 (2014), BR. 2 STR. 327-347

BAČIĆ, K., ŠIŠINAČKI, J.: CROATIA'S POTENTIAL... regions. Also, given the multidimensional aspect of the issue of polycentricity, sectoral policies should be complementary to polycentric development policies and therefore, the role of sectoral policies should be assessed and the concept of polycentricity should be integrative to those sectoral policies that are supportive of achieving more harmonious growth and development across Croatia.

\section{ACKNOWLEDGEMENTS}

We would like to thank two anonymous referees and our colleague Valerija Botrić for their helpful comments. We also thank Krešimir Mladiček for his technical assistance in preparing the paper. The usual disclaimer applies.

\section{NOTES}

\section{REFERENCES}

1 Similar examples of polycentric urban regions are the Flemish Diamond in Belgium (Brussels, Leuven, Antwerp and Ghent); Rhine-Ruhr in Germany (Dortmund, Essen, Dusseldorf, Cologne and Bonn) and the Padua-Treviso-Venice area in Italy.

2 Most of the EU countries have a national definition of FUAs, depending on the labour market data.

${ }^{3}$ However, a well-documented counter effect of developing the motorway that may occur is "the tunnel effect" whereby only the end points (i.e. cities) of the motorway benefit from its development.

4 This rule was not applicable in two counties with urban centres with less than 20,000 inhabitants. Instead, the largest city was used in the indicator.

Gløersen, E. (2005). European Typologies of Urban Systems. Presentation from the ESPON conference on European Territorial Research, 13-14 October 2005.

Government of the Republic of Croatia [Vlada Republike Hrvatske] (2004). Program građenja i održavanja javnih cesta za razdoblje od 2005. do 2008. godine [Programme for the Construction and Maintenance of Public Roads in the period 2005-2008]. Zagreb: Government of the Republic of Croatia.

Government of the Republic of Croatia [Vlada Republike Hrvatske] (2006). Strateški okvir za razvoj 2006.-2013. [Strategic Development Framework 2006-2013]. Zagreb: Central Office for Development Strategy and Coordination of EU Funds.

Government of the Republic of Croatia [Vlada Republike Hrvatske]. Program Vlade Republike Hrvatske za mandat 2011. - 2015. [Programme of the Government of the Republic of Croatia for the mandate 2011-2015], December 2011. Available at http://www.vlada.hr/

Hague, C., \& Kirk, K. (2003). Polycentricity scoping study. Edinburgh: Heriot-Watt University, School of the Built Environment. 
DRUŠ. ISTRAŽ. ZAGREB GOD. 23 (2014), BR. 2, STR. 327-347

BAČIĆ, K., ŠIŠINAČKI, J.: CROATIA'S POTENTIAL...
Kranjčević, J. (2005). Proces pridruživanja Europskoj uniji i prostorno uređenje Hrvatske [The process of accession to the EU and regional spatial development of Croatia]. In K. Ott (Ed.), Pridruživanje Hrvatske Europskoj uniji - ususret izazovima pregovora [Croatian accession to the EU - Facing the challenges of negotiations] (pp. 223-240). Zagreb: Institut za javne financije and Friedrich Ebert Stiftung.

Meijers, E., \& Sandberg, K. (2006). Polycentric development to combat regional disparities? The relation between polycentricity and regional disparities in European countries. Proceedings from the 46th Congress of the European Regional Science Association, Volos, August 30th September 3rd, 2006. Volos: University of Thessaly.

Meijers, E. J., Waterhout, B., \& Zonneveld, W. A. M. (2007). Closing the gap: Territorial cohesion through polycentric development. European Journal of Spatial Development, 24 (Refereed Articles). Available at http://www.nordregio.se/EJSD/refereed24.pdf

MRDEUF - Ministry of Regional Development and EU Funds (2010). Strategy on regional development of the Republic of Croatia 2011 - 2013, May, Version 1.0. Available at http://www.mrrfeu.hr.

MSPRC - Ministry of Spatial Planning of the Republic of Croatia [MPURH - Ministarstvo prostornog uređenja Republike Hrvatske] (1997). Strategija prostornog uređenja Republike Hrvatske [The spatial planning strategy of the Republic of Croatia]. Zagreb: Ministry of Spatial Planning of the Republic of Croatia, Institute for Spatial Planning.

MSPRC - Ministry of Spatial Planning of the Republic of Croatia [MPURH - Ministarstvo prostornog uređenja Republike Hrvatske] (1999). Program prostornog uređenja Republike Hrvatske [The spatial planning programme of the Republic of Croatia]. Zagreb: Ministry of Spatial Planning of the Republic of Croatia, Institute for Spatial Planning.

Nordregio (2005). ESPON 1.1.1. Potentials for Polycentric Development in Europe, Final report. Stockholm: Nordregio. Available at http:// www.espon.eu/.

Waterhout, B., Zonneveld, W., \& Meijers, E. (2005). Polycentric development policies in Europe: Overview and debate. Built Environment, 31(2), 163-173. http://dx.doi.org/10.2148/benv.31.2.163.66250

\section{SOURCES OF DATA}

CBS - Croatian Bureau of Statistics. Statistical Yearbook 2012. Available at http://www.dzs.hr/default_e.htm CBS - Croatian Bureau of Statistics. Statistical Yearbook 2001. Available at http://www.dzs.hr/ default_e.htm

CBS - Croatian Bureau of Statistics. Persons in paid employment, by activities and counties - Situation as on 31 March 2009. First Release, 31 March 2009. Available at http://www.dzs.hr/default_e.htm

CBS - Croatian Bureau of Statistics. Gross Domestic Product for Republic of Croatia, Statistical regions at Level 2 and counties, 2009. First Release, 14 March 2012. Available at http://www.dzs.hr/default_e.htm CBS - Croatian Bureau of Statistics (2010). Employment and Wages, 2009, Statistical Reports, 1419, Zagreb: CBS. Available at http://www. 
DRUŠ. ISTRAŽ. ZAGREB GOD. 23 (2014), BR. 2, STR. $327-347$

BAČIĆ, K., ŠIŠINAČKI, J.: CROATIA'S POTENTIAL...
CBS - Croatian Bureau of Statistics. Census 2011 - First Results (accessed in January 2013). Available at http://www.dzs.hr/default_e.htm

CBS - Croatian Bureau of Statistics. Foreign trade in goods of the Republic of Croatia by counties, towns and municipalities January - December 2009. First Release, 11 February 2010. Available at http://www.dzs.hr/ default_e.htm

Croatian Employment Service. Yearbook 2009. Available at http:// www.hzz.hr

Eurostat. Available at http://epp.eurostat.ec.europa.eu/portal/page/ portal/eurostat/home

GADM database of Global Administrative Areas. Available at http:// www.gadm.org/

OpenStreetMap. Available at http://www.openstreetmap.org/

\section{Potencijal Hrvatske za policentrični razvitak}

Katarina BAČIĆ

Ekonomski institut, Zagreb

Jelena ŠIŠINAČKI

Rabac

Cili je ovoga rada bio istražiti ima li Hrvatska potencijal za usvajanje koncepcije policentričnoga razvitka kao

ravnomjernoga razvitka podjednako udaljenih urbanih središta, kojem je i svrha smanjenje regionalnih nejednakosti, u svojoj regionalnoj razvojnoi politici. Primjenom indeksa policentričnosti prema metodološkom pristupu Meijers i Sandberga (2006) na hrvatske podatke, ustanovljeno je da je Hrvatska umjereno policentrična. No distribucija gradova prema poretku i veličini pokazuje da je Zagreb prevelik, dok su veći gradovi koji slijede Zagreb nedovolino veliki. Nadalje, miere regionalnih nejednakosti za Hrvatsku upućuju na prosječan stupani nejednakosti u usporedbi s Europskom unijom kada se koriste podaci NUTS razine 2, a kada se koriste podaci o županijama, stupani nejednakosti se povećava. To pokazuje da policentričnost nije potpuno iskorištena u pogledu povezanosti i suradnje gradova. Analizom presjeka regionalnih nejednakosti u Hrvatskoj utvrđeno je da su uspješnije županije koje imaju veći udio radne snage većeg obrazovnog dostignuća. $U$ rezultatima specifikacije modela $u$ kojem je izostavljena varijabla "radna snaga većeg obrazovnog dostignuća", urbani utjecaj i otvorenost prema međunarodnoj trgovini pokazuju se značajnima, pa su uspješnije županije koje imaju veći udio stanovništva u svojim urbanim središtima i koje su otvorenije prema međunarodnoj trgovini.

Ključne riječi: policentričnost, regionalni razvitak, analiza presjeka, Hrvatska 